\title{
Diversity of Bacillus thuringiensis environmental isolates showing larvicidal activity specific for mosquitoes
}

\author{
TAKAAKI IsHII and MichIo OHBA*
}

Institute of Biological Control, Faculty of Agriculture, Kyushu University, Fukuoka 812, Japan

(Received 5 April 1993; revised 24 June 1993; accepted 6 July 1993)

\begin{abstract}
Seven mosquito-specific strains of Bacillus thuringiensis isolated in Japan were examined for their flagellar (H) antigenicities and the properties of parasporal inclusion proteins. They were assigned to six $H$ serovars: serovar fukuokaensis (H 3ade); serovar canadensis (H 5ac); serovar darmstadiensis (H 10); serovar kyushuensis (H 11ac); serovar shandongiensis (H 22); and an undescribed serovar belonging to $H$ serotype 20 . Purified parasporal inclusions exhibited moderate mosquito larvicidal activities with $\mathrm{LC}_{50}$ values ranging from $1 \mu \mathrm{g} \mathrm{ml}^{-1}$ to $10 \mu \mathrm{g} \mathrm{ml}^{-1}$. The inclusions of these strains consisted of highly heterogeneous multiple protein components, and five distinct patterns were evident in their SDS-PAGE profiles. Antibodies against kyushuensis inclusion proteins were reactive with all strains to varying degrees, while israelensis antibodies gave only relatively weak reactions with the seven strains. Similarity in antibody-binding profiles was associated with similarity in SDS-PAGE profiles. In a given strain, different antisera gave altered immunoblot profiles. Haemolytic activity was shown by solubilized parasporal inclusion proteins of five of the seven strains.
\end{abstract}

\section{Introduction}

Goldberg \& Margalit (1977) isolated a Bacillus strain possessing a high larvicidal activity, specific for mosquitoes, from the soil of a mosquito-breeding site in Israel. On the basis of this strain, de Barjac (1978) established the Bacillus thuringiensis serovar israelensis (H antigen 14). Thereafter, many workers have reported the occurrence of highly mosquitocidal $B$. thuringiensis strains, belonging to serovar israelensis (Balaraman et al., 1981; Zhang et al., 1984; Shim et al., 1990; AbdelHameed et al., 1990), serovar morrisoni (Padua et al., 1984), and serovar medellin (Orduz et al., 1992), in various regions of the world. However, it is generally accepted that the mosquito-specific $B$. thuringiensis, with moderate to low toxicities, is also disseminated in natural environments. In fact, our surveys on the geographical distribution of this bacterium in Japan have found many strains with moderate toxicity levels (Ohba \& Aizawa, 1979, 1986a, 1990; Padua et al., 1980; T. Ishii \& M. Ohba, unpublished results). Properties of highly toxic strains have been investigated extensively because of their possible use for microbial control of medically important dipterous pests (de Barjac \& Sutherland,

*Author for correspondence. Tel +81926411101; fax +8192632 1964.
1990). In contrast, only a few studies have focused on the group with moderate to low toxicities.

In this paper, we describe the comparative characterization of moderately toxic strains isolated in Japan. Our study shows that the populations of mosquito-specific $B$. thuringiensis in Japan are highly heterogeneous in flagellar antigenic structure and in the composition of parasporal inclusions.

\section{Methods}

Bacteria. The seven Japanese strains of $B$. thuringiensis used in this study are listed in Table 1 . Of these, three reference strains were from the culture collection of this institute. Four other strains were newly isolated in this study from soils in Japan according to the method of Ohba \& Aizawa (1986b). The type strains of $B$. thuringiensis serovar israelensis and serovar sotto $(\mathrm{H} 4 \mathrm{ab})$ were also used as a mosquitocidal reference and a Lepidoptera-specific control, respectively. To prepare sporulated cultures, bacteria were grown on nutrient agar, $\mathrm{pH} \mathrm{7.8,} \mathrm{at}$ $27^{\circ} \mathrm{C}$ for $4 \mathrm{~d}$. Formation of spores and parasporal inclusions was monitored by phase-contrast microscopy.

Qualitative and quantitative toxicity tests. Four B. thuringiensis strains, newly isolated in this study, were examined for their qualitative larvicidal activity against three species of Lepidoptera and two species of Diptera. To test the toxicity against the silkworm, Bombyx mori, ten third- to fourth-instar larvae were fed at $25^{\circ} \mathrm{C}$ for $3 \mathrm{~d}$ on a mulberry leaf smeared with $0.2 \mathrm{ml}$ spore/parasporal inclusion mixture (approximately $10^{8}$ spores $\mathrm{ml}^{-1}$ ). For the tests with the fall webworm, Hyphantria cunea, and the smaller tea tortrix, Adoxophyes orana, five to ten larvae (fourth or fifth instar) were fed for $7 \mathrm{~d}$ on a bacteria- 
Table 1. Japanese strains of B. thuringiensis used in this study

\begin{tabular}{|c|c|c|c|}
\hline B. thuringiensis strain & $\begin{array}{c}\text { Flagellar }(\mathrm{H}) \\
\text { antigen }\end{array}$ & H serovar & Source or reference \\
\hline $\begin{array}{l}\text { Type strain of serovar } \\
\text { kyushuensis }\end{array}$ & $11 \mathrm{ac}$ & kyushuensis & Ohba \& Aizawa (1979) \\
\hline $84-I-1-13$ & 3ade & fukuokaensis & Ohba \& Aizawa (1990) \\
\hline $73-\mathrm{E}-10-2$ & 10 & darmstadiensis & Padua et al. (1980) \\
\hline $88-K G-2-21$ & 10 & darmstadiensis & This study, soil, Kagawa Pref. \\
\hline $89-\mathrm{T}-5-9$ & $5 \mathrm{ac}$ & canadensis & This study, soil, Tokyo \\
\hline $89-T-34-14$ & $20^{*}$ & - & This study, soil, Tokyo \\
\hline 89-ST-1-25 & 22 & shandongiensis & This study, soil, Saitama Pref. \\
\hline
\end{tabular}

* Not seroreactive for $20 \mathrm{~b}$ and $20 \mathrm{c}$ factor sera.

contaminated artificial diet $(0.3-0.5 \mathrm{ml}$ bacterial suspension per $10 \mathrm{~g}$ diet). The type strain of serovar sotto was also tested in the same manner as a Lepidoptera-toxic control. Toxicity tests with the mosquitoes, Aedes aegypti and Culex pipiens pallens, were done by introducing 10 to 20 larvae (3-4-d-old) into a test tube containing $10 \mathrm{ml}$ bacterial suspension (approximately $10^{7}$ spores $\mathrm{ml}^{-1}$ ). Mosquito larvae were kept at $25^{\circ} \mathrm{C}$ and the mortality was examined daily for $2 \mathrm{~d}$.

Quantitative toxicity tests were performed with purified parasporal inclusions. Twofold serial dilutions were prepared in distilled water. For the assay with $B$. mori, 20 second-instar larvae were fed at $25^{\circ} \mathrm{C}$ for $3 \mathrm{~d}$ on an artificial diet $(2.5 \mathrm{~g})$ contaminated with $0.1 \mathrm{ml}$ of each dilution. Assays were done in duplicate. The test with $A$. aegypti was done by introducing 30 second-instar larvae into $15 \mathrm{ml}$ of each dilution. Larvae were kept unfed at $25^{\circ} \mathrm{C}$ and the $24 \mathrm{~h}$ mortality was scored. Assays were done in triplicate and the $\mathrm{LC}_{50}$ values were determined by probit analysis (Finney, 1952).

$H$ serotyping. Reference $\mathrm{H}$ antisera to the type strains of the known $B$. thuringiensis $\mathrm{H}$ antigenic serovars were prepared according to the method of Ohba \& Aizawa (1978). For H serotyping of the strains, actively motile bacteria were selected by passing through Craigie's tubes at $37^{\circ} \mathrm{C}$ for $24 \mathrm{~h}$. Slide agglutination was performed by mixing one drop of 3-4-h-old flagellated broth culture of the bacteria on a glass slide with one drop of $20-50$-fold dilution of $\mathrm{H}$ antiserum. Specific $\mathrm{H}$ agglutination was determined 3-5 min after mixing.

Purification and solubilization of parasporal inclusions. Sporulated cultures were harvested by centrifugation at $10000 \mathrm{~g}$ for $20 \mathrm{~min}$ at $4{ }^{\circ} \mathrm{C}$, and the pellet was washed three or four times by centrifugation in $1 \mathrm{M}-$ $\mathrm{NaCl}$ at $4{ }^{\circ} \mathrm{C}$. Parasporal inclusions were partially purified by a biphasic separation technique (Goodman et al., 1967) using dextran sulphate/polyethylene glycol. The lower phase, containing parasporal inclusions, was collected and washed three times in distilled water by centrifugation. Further purification was done by $\mathrm{NaBr}$ density-gradient centrifugation according to the method of Held et al. (1990). The isolated inclusions were washed three times with distilled water and their purity was monitored by phase-contrast microscopy. Purified parasporal inclusions were suspended in distilled water and stored at $-20^{\circ} \mathrm{C}$ until needed.

Parasporal inclusions were solubilized by treatment at $37^{\circ} \mathrm{C}$ for $60 \mathrm{~min}$ in $50 \mathrm{~mm}-\mathrm{Na}_{2} \mathrm{CO}_{3}$ (pH 10.0)/10 mM-dithiothreitol (DTT)/ 1 mM-EDTA. Insoluble materials were pelleted by centrifugation at $10000 \mathrm{~g}$ for $10 \mathrm{~min}$ at $4{ }^{\circ} \mathrm{C}$, and the resulting supernatant was referred to as solubilized parasporal inclusions.

Protease treatment of solubilized parasporal inclusions. Solubilized inclusion proteins $\left(1 \mathrm{mg} \mathrm{m}^{-1}\right)$ were treated with proteinase $\mathrm{K}(10 \mu \mathrm{g}$ $\mathrm{ml}^{-1}$; Sigma) at $37^{\circ} \mathrm{C}$ for $30 \mathrm{~min}$. The reaction was stopped by addition of 1 mM-PMSF.

Protein determination. Protein concentrations were determined by the Bio-Rad Protein Assay Kit with bovine IgG as the standard.
$S D S-P A G E$. SDS-PAGE was performed as described by Laemmli (1970), using $10 \%$ separating and $4 \%$ stacking gels. After electrophoresis, the gels were stained with $0.1 \%(\mathrm{w} / \mathrm{v})$ Coomassie blue R-250 (Sigma). The molecular masses of proteins were determined by using protein standards obtained from Sigma.

Production of inclusion protein antibodies and immunoblotting. Antisera were raised in rabbits against parasporal inclusion proteins of the type strains of $B$. thuringiensis serovar israelensis and serovar kyushuensis. Rabbits were immunized by three subcutaneous injections, at weekly intervals, of the solubilized parasporal inclusions, mixed with an equal volume of Freund's complete adjuvant (Difco). One week later, these were followed by intravenous booster injections of adjuvantfree solubilized inclusion proteins. The rabbits were bled one week after the last intravenous injection. The total amount of inclusion proteins injected was $2 \mathrm{mg}$ and $9 \mathrm{mg}$ for serovar kyushuensis and serovar israelensis, respectively. IgG fractions were purified with ImmunoPure IgG Purification Kit (Pierce) according to manufacturer's instructions.

For immunoblot analysis (Towbin et al., 1979), the separated proteins were transferred electrophoretically from an SDSpolyacrylamide gel to a polyvinylidene difluoride (PVDF) membrane using an ATTO Holizblot (ATTO) according to the manufacturer's instructions. The transferred proteins were probed first with a $1: 2000$ dilution of primary antibodies (IgG fractions: $1 \mathrm{mg} \mathrm{m}^{-1}$ ) followed by a 1:2000 dilution of goat anti-rabbit IgG-conjugated alkaline phosphatase (TAGO). Visualization was performed with nitro blue tetrazolium chloride and 5-bromo-4-chloro-3-indolyl toluidinate (Wako Pure Chemical) as the colour substrate.

Haemolytic activity. Human (blood group $\mathrm{AB}$ ) erythrocytes were washed twice by centrifugation at $800 \mathrm{~g}$ with $20 \mathrm{mM}$-Tris-buffered saline, $\mathrm{pH} 8.0$. They were then resuspended to a concentration of $2 \%$ (v/v) in Tris-buffered saline, and twofold serial dilutions of solubilized inclusion preparations were made in the same solution. The dilution $(100 \mu l)$ was mixed with an equal volume of $2 \%$ erythrocyte suspension in a well of a round-bottomed 96-well microtitre plate (Sanko). After incubation for $18 \mathrm{~h}$ at $27^{\circ} \mathrm{C}$, the plate was centrifuged at $800 \mathrm{~g}$ for $10 \mathrm{~min}$, and the supernatant was examined for the amount of haemoglobin released. Haemolytic activity was expressed as units per $\mathrm{mg}$ protein; one unit was defined as the activity required to increase the absorbance at $540 \mathrm{~nm}$ by 0.1 after $18 \mathrm{~h}$ incubation at $27^{\circ} \mathrm{C}$. Each assay was repeated three times.

\section{Results}

$H$ serotyping and insecticidal activity

$\mathrm{H}$ antigenicities of the three reference strains and the four new soil isolates were analysed by slide agglutination tests with the $\mathrm{H}$ antisera against the known serovars of $B$. 
Table 2. Mosquito larvicidal activity of purified parasporal inclusions from eight $B$. thuringiensis strains

\begin{tabular}{lc}
\hline \multicolumn{1}{c}{ Strain } & $\begin{array}{c}\mathrm{LC}_{50}\left(\mu \mathrm{g} \mathrm{ml}^{-1}\right) \text { for } \\
\text { second-instar larvae of } \\
\text { Aedes aegypti* }\end{array}$ \\
\hline israelensis type strain & $0.010(0 \cdot 009-0 \cdot 013)$ \\
kyushuensis type strain & $3.69(3 \cdot 04-4 \cdot 52)$ \\
84-I-1-13 & $1 \cdot 73(1 \cdot 21-2 \cdot 28)$ \\
73-E-10-2 & $1 \cdot 48(1 \cdot 28-1 \cdot 71)$ \\
88-KG-2-21 & $1 \cdot 15(0 \cdot 96-1 \cdot 31)$ \\
89-T-5-9 & $1 \cdot 02(0 \cdot 73-1 \cdot 30)$ \\
89-T-34-14 & $10.34(9 \cdot 07-11 \cdot 95)$ \\
89-ST-1-25 & $2 \cdot 64(2 \cdot 20-3 \cdot 14)$ \\
\hline \hline
\end{tabular}

* The fiducial limit at the $95 \%$ level is given in parentheses.

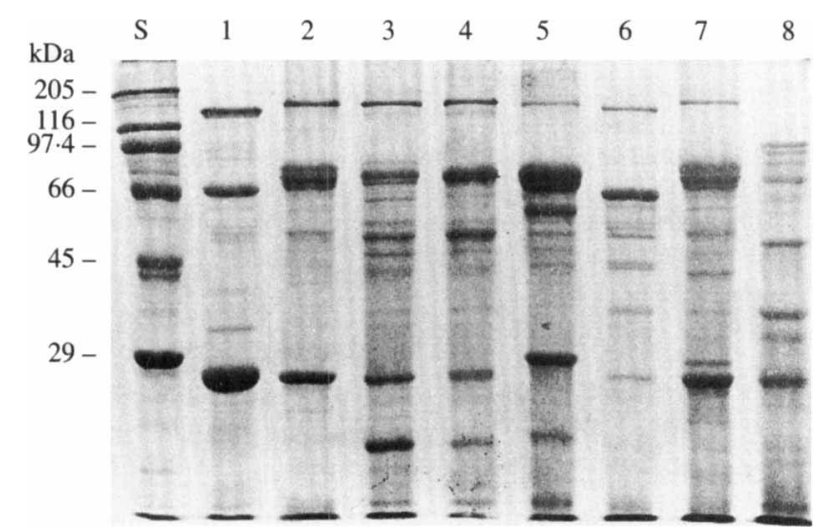

Fig. 1. Comparative SDS-PAGE of parasporal inclusion proteins from mosquito-specific $B$. thuringiensis strains. Lanes: 1, the type strain of $B$. thuringiensis serovar israelensis; 2 , the type strain of serovar kyushuensis; 3 and 4, strains of serovar darmstadiensis, 73-E-10-2 and 88-KG-2-21; 5, strain 89-T-34-14 (undescribed serovar belonging to serotype 20); 6, strain 89-T-5-9 (serovar canadensis); 7, strain 89-ST-125 (serovar shandongiensis); 8, strain 84-I-1-13 (serovar fukuokaensis); $\mathrm{S}$, protein standards. Each lane contained $10 \mu \mathrm{g}$ inclusion proteins. The gel was stained with Coomassie brilliant blue.

thuringiensis. As shown in Table 1, six strains were assigned to the five known serovars of $B$. thuringiensis. One isolate, designated 89-T-34-14, was seropositive to $\mathrm{H}$ antiserum against serovar yunnanensis $(\mathrm{H}$ antigen $20 \mathrm{ab}$ ). However, it did not react with factor sera against $20 \mathrm{~b}$ and $20 \mathrm{c} \mathrm{H}$ antigenic subfactors.

Qualitative oral toxicity tests revealed that spore/ parasporal inclusion mixtures of the four new soil isolates were all toxic to mosquito larvae; they produced 90-100\% mortality in A. aegypti and C. pipiens pallens in $2 \mathrm{~d}$. In contrast, there was no mortality in three species of Lepidoptera. The type strain of serovar sotto exhibited toxicity to lepidopterous larvae.

Mosquito larval $\mathbf{L C}_{50}$ values of the purified inclusions were determined. Inclusions of the seven Japanese strains had $\mathrm{LC}_{50}$ values ranging from $1 \mu \mathrm{g} \mathrm{m}^{-1}$ to $10 \mu \mathrm{g} \mathrm{ml}^{-1}$ (Table 2). They were $100-1000$ times less toxic than israelensis inclusions. No mortality was induced in second-instar B. mori larvae by these mosquitocidal strains, even at a high inclusion concentration of $1 \mathrm{mg}$ $\mathrm{ml}^{-1}$.

\section{SDS-PAGE analysis of parasporal inclusion proteins}

Purified parasporal inclusions of the type strain of serovar israelensis and the seven Japanese strains were examined for their protein components by SDS-PAGE (Fig. 1). Parasporal inclusions of the strains consisted of highly heterogeneous multiple protein components, with molecular masses ranging from $20-29 \mathrm{kDa}$ to 130 $140 \mathrm{kDa}$. The major protein profile of serovar israelensis was substantially different from those of the seven Japanese strains, among which five distinct patterns were observed in their SDS-PAGE profiles. The strain of serovar shandongiensis (89-ST-1-25) had a protein profile similar to that of the type strain of serovar kyushuensis. Similarity in the major protein profiles was also evident between the two strains of serovar darmstadiensis, 73-E10-2 and 88-KG-2-21, although a minor difference was observed. Inclusions of the three other strains had different protein profiles. Of several major proteins, the $130-140 \mathrm{kDa}$ proteins were commonly detected in the type strain of israelensis and the six Japanese strains, with only strain 84-I-1-13 (serovar fukuokaensis) lacking the protein of this class. Proteins of the $25-29 \mathrm{kDa}$ class were present in all strains tested; the $20 \mathrm{kDa}$ proteins were detected in the two darmstadiensis strains and the strain belonging to serotype 20 .

\section{Immunoblot analysis}

As shown in Fig. 2(b), antibodies against inclusion proteins of the serovar kyushuensis strain reacted strongly, not only with homologous proteins $(25 \mathrm{kDa}$, $60-70 \mathrm{kDa}$ and $150 \mathrm{kDa}$ ), but with all major proteins (25 kDa, $60-70 \mathrm{kDa}$ and $150 \mathrm{kDa}$ ) of the strain 89-ST-125 belonging to serovar shandongiensis. Immunoblot profiles of these two strains were very similar to each other. Further, kyushuensis antibodies showed immunoreactivity to inclusion proteins of the other mosquitocidal strains. In particular, inclusion proteins of the two darmstadiensis strains, 73-E-10-2 and 88-KG-2-21, and the strain 89-T-34-14 (serotype 20), strongly crossreacted; however, immunoblot profiles of the two darmstadiensis strains were quite different from that of strain 89-T-34-14. The two other strains, serovar canadensis and serovar fukuokaensis, reacted weakly with kyushuensis antibodies.

The antibodies of serovar israelensis reacted strongly with the homologous antigens and moderately with $14-15 \mathrm{kDa}$ inclusion proteins of the kyushuensis type strain and the strain 89-ST-1-25 of serovar shandongiensis 


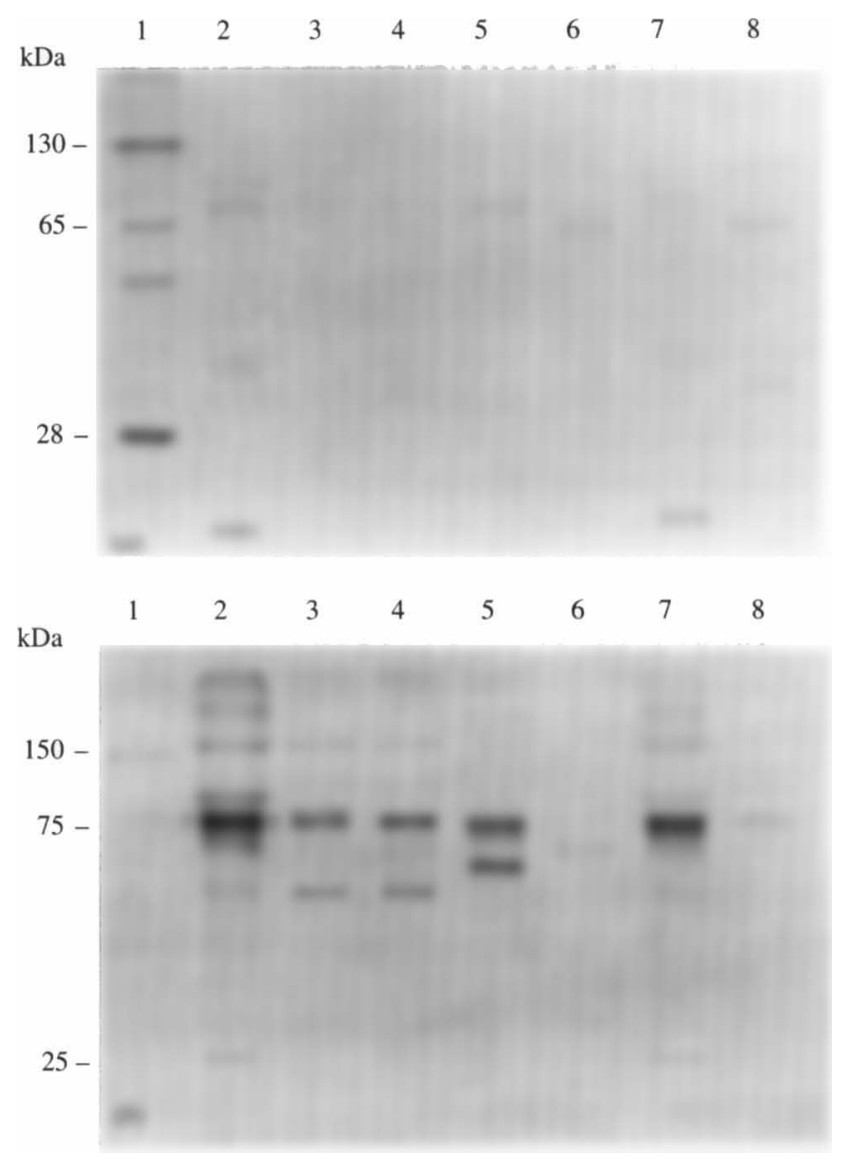

Fig. 2. Immunoblots of parasporal inclusion proteins from the mosquito-specific strains of $B$. thuringiensis. The proteins were probed with antibodies raised against solubilized inclusion proteins of $(a) B$. thuringiensis serovar israelensis and $(b)$ the type strain of serovar kyushuensis. Each lane contained $100 \mathrm{ng}$ inclusion proteins. Lanes: 1, the type strain of serovar israelensis; 2 , the type strain of serovar kyushuensis; 3 and 4, strains of serovar darmstadiensis, 73-E-10-2 and 88-KG-2-21; 5, strain 89-T-34-14 (undescribed serovar belonging to serotype 20); 6, strain 89-T-5-9 (serovar canadensis); 7, strain 89-ST-125 (serovar shandongiensis); 8, strain 84-I-1-13 (serovar fukuokaensis). Pointers correspond to the positions $(\mathrm{kDa})$ of protein standards in SDS-PAGE.

(Fig. 2a). Other heterologous strains exhibited only weak cross-reactions with israelensis antibodies. Binding of the antibodies to standard proteins was not observed in this study. In addition, binding of non-immune antibodies to parasporal inclusion proteins was not evident.

\section{Haemolytic activity}

Solubilized parasporal inclusions of the seven Japanese strains and the type strain of serovar israelensis were examined for their haemolytic activity against human erythrocytes. As shown in Table 3, most strains showed haemolytic activity. However, it was not detected in two strains, 89-T-5-9 (serovar canadensis) and 89-T-34-14 (serotype 20 ), even at a high protein concentration of
Table 3. Haemolytic activity of solubilized parasporal inclusions against human erythrocytes

\begin{tabular}{lcc}
\hline \hline & Haemolytic activity (units per mg protein)* \\
\cline { 2 - 3 } Strain & $\begin{array}{c}\text { Solubilized parasporal } \\
\text { inclusions } \dagger\end{array}$ & $\begin{array}{c}\text { Solubilized and } \\
\text { protease-treated } \\
\text { parasporal inclusions }\end{array}$ \\
\hline Reference strains & & \\
israelensis & 160 & 320 \\
kyushuensis & 10 & 80 \\
73-E-10-2 & $2 \cdot 5$ & 40 \\
84-I-1-13 & $2 \cdot 5$ & 0 \\
Soil isolates & & 20 \\
88-KG-2-21 & 5 & 0 \\
89-T-34-14 & 0 & 0 \\
89-T-5-9 & 0 & 40 \\
89-ST-1-25 & 10 & \\
\hline \hline
\end{tabular}

* One unit was defined as the activity required to increase the absorbance at $540 \mathrm{~nm}$ by 0.1 after $18 \mathrm{~h}$ incubation at $27^{\circ} \mathrm{C}$.

† The solubilization was performed with $50 \mathrm{~mm}-\mathrm{Na}_{2} \mathrm{CO}_{3} / 10 \mathrm{~mm}-$ DTT/1 mM-EDTA.

$\ddagger$ Solubilized parasporal inclusions were treated with proteinase $\mathrm{K}$ at a final concentration of $10 \mu \mathrm{g} \mathrm{ml}^{-1}$.

$1 \mathrm{mg} \mathrm{m}^{-1}$. Among the positive strains, serovar israelensis had the highest level of haemolytic activity, while the other strains had low activities. Proteinase K treatment of solubilized inclusions of all but one of the positive strains resulted in a marked increase in their haemolytic activities; the activity of the fukuokaensis strain (84-I-113) was destroyed by this treatment. Solubilized inclusions of the two strains, 89-T-5-9 (serovar canadensis) and 89-T-34-14 (serotype 20), did not show any haemolytic activity even after treatment with proteinase K.

\section{Discussion}

B. thuringiensis strains exhibiting mosquito-specific toxicity are widely found in soils and insect-breeding environments in Japan (Ohba \& Aizawa, 1979, 1986b; Padua et al., 1980; T. Ishii \& M. Ohba, unpublished results). They have been assigned to serovars kyushuensis (Ohba \& Aizawa, 1979, 1986a), darmstadiensis (Padua et al., 1980), fukuokaensis (Ohba \& Aizawa, 1990), amagiensis and an undescribed serovar (T. Ishii \& M. Ohba, unpublished results). In the present study, three more serovars were added to the mosquito-specific $B$. thuringiensis flora in Japan, indicating that the bacterial populations of this pathotype are highly heterogeneous in $\mathrm{H}$ antigenic structures. Wang et al. (1986) and Pietrantonio \& Gill (1992) reported that the type strain of the serovar shandongiensis has no insecticidal activity against the larvae of Diptera and Lepidoptera. In addition, mosquito-toxic strains are presently unknown in the serovar canadensis. Thus, this 
report is the first to show the occurrence of mosquitocidal strains in these two serovars of $B$. thuringiensis. The occurrence of two or more pathotypes in a given serogroup has been demonstrated in serovars darmstadiensis (Padua et al., 1980), morrisoni (Padua et al., 1984; Krieg et al., 1987) and fukuokaensis (Ohba \& Aizawa, 1990). These findings, together with the present results, show the discrepancy between $\mathrm{H}$ antigenicity and insecticidal properties, although a general correlation is evident between these two phenotypes.

The seven Japanese strains were similar in that they produced spherical to irregular-shaped parasporal inclusions. We detected five distinct patterns in SDSPAGE profiles of these mosquito-specific parasporal inclusions, although some similarity was also observed between the patterns. Protein profiles for the type strain of kyushuensis and the two reference strains, 73-E-10-2 and 84-I-1-13, were consistent with those observed by previous investigators (Earp et al., 1987; Drobniewski \& Ellar, 1989; Held et al., 1990; Yu et al., 1991; Ishii \& Ohba, 1992). Parasporal inclusions of most strains contained proteins with high molecular masses of $130-140 \mathrm{kDa}$. At present, little information is available on the actual mosquitocidal toxins in these strains. However, it is likely that the $130-140 \mathrm{kDa}$ proteins are primarily responsible for mosquitocidal activity, because the proteins of this class are the protoxins in most insecticidal strains of $B$. thuringiensis, including serovar israelensis (Höfte \& Whiteley, 1989).

Interestingly, parasporal inclusions of the serovar fukuokaensis strain (84-I-1-13) lacked the protein of this class. Yu et al. (1991) suggested that the proteins of $72-90 \mathrm{kDa}$ are the protoxin in this strain. Kim et al. (1984) isolated a $67 \mathrm{kDa}$ larvicidal protein from parasporal inclusions of the strain 73-E-10-2. However, it is likely that this protein is a proteolysis product of the higher-molecular-mass protoxin.

There was a high similarity in protein profiles between the strain of serovar shandongiensis (89-ST-1-25) and the type strain of kyushuensis. A high similarity between the two was also shown in immunoblot analysis with kyushuensis antibodies. In another study of ours (T. Ishii \& M. Ohba, unpublished results), kyushuensis-type parasporal inclusions were found in several soil isolates belonging to serovar amagiensis and an undescribed serovar. Our results suggest that the kyushuensis-type inclusion is widely disseminated in multiple serovars of B. thuringiensis.

It has been demonstrated that the parasporal inclusions of the existing mosquito-specific $B$. thuringiensis strains are immunologically related to varying degrees (Earp et al., 1987; Padua et al., 1988; Held et al., 1990; Cheung \& Kim, 1990; Yu et al., 1991; Ishii \& Ohba, 1992). In this study, we showed that mosquito-specific strains tested shared common inclusion protein antigens with both type strains of kyushuensis and israelensis to various extents. It is noteworthy that the two antibodies gave different immunoblot profiles to a given strain. Interestingly, the 14-15 kDa proteins of kyushuensis and shandongiensis strains showed substantial immunoreactivity to israelensis antibodies, while no immunobinding of kyushuensis antibodies occurred. At present, no explanation is available for this contradictory result.

It is well accepted that the $25-29 \mathrm{kDa}$ proteins of mosquito-specific $B$. thuringiensis strains are cytolytic, upon proteolytic digestion, for vertebrate and insect cells (Thomas \& Ellar, 1983; Gill \& Hornung, 1987; Yu et al., 1991; Knowles et al., 1992). In the present study, we detected proteins of this size in all strains tested. This is of interest because human erythrocyte lytic activity was not associated with two strains, 89-T-5-9 and 89-T-3414 , even after treatment with protease. However, more research with various cell types is needed, since previous workers have demonstrated that the activity of the $B$. thuringiensis cytolytic delta-endotoxin varies considerably, depending on the source of erythrocytes (Drobniewski \& Ellar, 1989). Several investigators have made the interesting observation that the $25 \mathrm{kDa}$ cytolytic proteins of israelensis and of strain PG-14 (serovar morrisoni) are of low toxicity to mosquitoes, but strongly enhance the mosquitocidal-activity of the other coexisting inclusion proteins (Wu \& Chang, 1985; Yu et al., 1987). Whether and how the 25-29 kDa proteins of our strains participate in killing mosquito larvae will be the subject of future work.

We thank Mr K. Miyamoto for assistance in testing the insecticidal activity of Bacillus thuringiensis strains against Lepidoptera. We also thank $\operatorname{Dr} \mathrm{T}$. Kawarabata for critically reading the manuscript.

\section{References}

Abdel-Hameed, A., Carlberg, G. \& El-Tayeb, O. M. (1990). Studies on Bacillus thuringiensis $\mathrm{H}-14$ strains isolated in Egypt. I. Screening for active strains. World Journal of Microbiology and Biotechnology 6, 299-304.

Balaraman, K., Hoti, S. L. \& Manonmani, L. M. (1981). An indigenous virulent strain of Bacillus thuringiensis, highly pathogenic and specific to mosquitoes. Current Science 50, 199-200.

CheunG, T.-Y. \& KIM, K.-H. (1990). Immunological characteristics of mosquitocidal delta-endotoxin from Bacillus thuringiensis subsp. darmstadiensis 73E10-2. Korean Journal of Applied Microbiology and Bioengineering 18, 301-304.

DE BARJAC, H. (1978). Une nouvelle variété de Bacillus thuringiensis très toxique pour les moustiques: $B$. thuringiensis var. israelensis sérotype 14. Comptes Rendus de l'Académie des Sciences, Série D 286, 797-800.

De Barjac, H. \& Sutherland, D. J. (1990). Bacterial Control of Mosquitoes and Black Flies. London: Unwin Hyman.

DrobniEwski, F. A. \& Ellar, D. J. (1989). Purification and properties of a 28-kilodalton hemolytic and mosquitocidal protein toxin of Bacillus thuringiensis subsp. darmstadiensis 73-E10-2. Journal of Bacteriology 171, 3060-3067.

EARP, D. J., WARD, E. S. \& EllaR, D. J. (1987). Investigation of possible homologies between crystal proteins of three mosquitocidal 
strains of Bacillus thuringiensis. FEMS Microbiology Letters 42 , 195-199.

Finney, D. J. (1952). Probit Analysis, 2nd edn. London: Cambridge University Press.

Gill, S. S. \& Hornung, J. M. (1987). Cytolytic activity of Bacillus thuringiensis proteins to insect and mammalian cell lines. Journal of Invertebrate Pathology 50, 16-25.

GoldberG, L. J. \& Margalit, J. (1977). A bacterial spore demonstrating rapid larvicidal activity against Anopheles sergentii, Uranotaenia unguiculata, Culex univittatus, Aedes aegypti and Culex pipiens. Mosquito News 37, 355-358.

Goodman, N. S., GotTrRied, R. J. \& Rogoff, M. H. (1967). Biphasic system for separation of spores and crystals of Bacillus thuringiensis. Journal of Bacteriology 94, 485.

Held, G. A., Kawanish, C. Y. \& Huang, Y.-S. (1990). Characterization of the parasporal inclusion of Bacillus thuringiensis subsp. kyushuensis. Journal of Bacteriology 172, 481-483.

HÖFTE, H. \& WHITELEY, H. R. (1989). Insecticidal crystal proteins of Bacillus thuringiensis. Microbiological Reviews 53, 242-255.

IsHII, T. \& OHBA, M. (1992). Immunological relationships between parasporal inclusions of Bacillus thuringiensis serovar kyushuensis and the three other mosquito-specific Bacillus thuringiensis strains. Journal of General and Applied Microbiology 38, 385-389.

Kim, K.-H., OHBa, M. \& Aizawa, K. (1984). Purification of the toxic protein from Bacillus thuringiensis serotype 10 isolate demonstrating a preferential larvicidal activity to the mosquito. Journal of Invertebrate Pathology 44, 214-219.

Knowles, B. H., White, P. J., Nicholls, C. N. \& Ellar, D. J. (1992). A broad-spectrum cytolytic toxin from Bacillus thuringiensis var. kyushuensis. Proceedings of the Royal Society of London B248, 1-7.

Krieg, A., Schnetter, W., Huger, A. L. \& Langenbruch, G. A. (1987). Bacillus thuringiensis subsp. tenebrionis, strain BI 256-82: a third pathotype within the H serotype 8a8b. Systematic and Applied Microbiology 9, 138-141.

LAEMMLI, U. K. (1970). Cleavage of structural proteins during the assembly of the head of bacteriophage T4. Nature, London 227, 680-685.

Ohba, M. \& Alzawa, K. (1978). Serological identification of Bacillus thuringiensis and related bacteria isolated in Japan. Journal of Invertebrate Pathology 32, 303-309.

OHBA, M. \& Aizawa, K. (1979). A new subspecies of Bacillus thuringiensis possessing 11a:11c flagellar antigenic structure: Bacillus thuringiensis subsp. kyushuensis. Journal of Invertebrate Pathology 33, 387-388.

OHBA, M. \& AlzAWA, K. (1986a). Insect toxicity of Bacillus thuringiensis isolated from soils of Japan. Journal of Invertebrate Pathology 47, 12-20.

OHBA, M. \& AIZAWA, K. (1986b). Distribution of Bacillus thuringiensis in soils of Japan. Journal of Invertebrate Pathology 47, 277-282.
OHBA, M. \& Aizawa, K. (1990). Occurrence of two pathotypes in Bacillus thuringiensis subsp. fukuokaensis (flagellar serotype 3a:3d:3e). Journal of Invertebrate Pathology 55, 293-294.

Orduz, S., Rojas, W., Correa, M. M., Montoya, A. E. \& De BarjaC, H. (1992). A new serotype of Bacillus thuringiensis from Colombia toxic to mosquito larvae. Journal of Invertebrate Pathology 59, 99-103.

Padua, L. E., Ohba, M. \& Aizawa, K. (1980). The isolates of Bacillus thuringiensis serotype 10 with a highly preferential toxicity to mosquito larvae. Journal of Invertebrate Pathology 36, 180-186.

Padua, L. E., OhBa, M. \& Aizawa, K. (1984). Isolation of a Bacillus thuringiensis strain (serotype $8 \mathrm{a}: 8 \mathrm{~b}$ ) highly and selectively toxic against mosquito larvae. Journal of Invertebrate Pathology 44, 12-17.

Padua, L. E., Ohba, M. \& Aizawa, K. (1988). Comparative serology of crystals produced by PG-14, Bacillus thuringiensis subsp. morrisoni (serotype $\mathrm{H} \mathrm{8a:8b)}$ and Bacillus thuringiensis subsp. israelensis (serotype H 14). Journal of Invertebrate Pathology 52, 192-194.

Pietrantonio, P. V. \& Gill, S. S. (1992). The parasporal inclusion of Bacillus thuringiensis subsp. shandongiensis: characterization and screening for insecticidal activity. Journal of Invertebrate Pathology 59, 295-302.

Shim, J. C., Yoon, Y. H., Yeon, K. N., Shim, S. B. \& YU, H. S. (1990). Isolation of Bacillus thuringiensis from soil and control effect of medically important insects. Korean Journal of Entomology 20, 179-188.

Thomas, W. E. \& Ellar, D. J. (1983). Bacillus thuringiensis var. israelensis crystal $\delta$-endotoxin: effects on insect and mammalian cells in vitro and in vivo. Journal of Cell Science 60, 181-197.

Towbin, H., Stakhelin, T. \& GoRdon, J. (1979). Electrophoretic transfer of proteins from polyacrylamide gels to nitrocellulose sheets: procedure and some applications. Proceedings of the National Academy of Sciences of the United States of America 76, 4350-4354.

WaNG, Y., Wen, J. \& FenG, X. (1986). A new serovar of Bacillus thuringiensis. Acta Microbiologica Sinica 26, 1-6.

WU, D. \& CHANG, F. N. (1985). Synergism in mosquitocidal activity of 26 and $65 \mathrm{kDa}$ proteins from Bacillus thuringiensis subsp. israelensis crystal. FEBS Letters 190, 232-236.

Yu, Y. M., OHBa, M. \& Aizawa, K. (1987). Synergistic effects of the 65- and 25-kilodalton proteins of Bacillus thuringiensis strain PG-14 (serotype 8a:8b) in mosquito larvicidal activity. Journal of General and Applied Microbiology 33, 459-462.

YU, Y. M., OHBA, M. \& GILL, S. S. (1991). Characterization of mosquitocidal activity of Bacillus thuringiensis subsp. fukuokaensis crystal proteins. Applied and Environmental Microbiology 57, 1075-1081

Zhang, Y., Ku, Z., Chen, Z., Xu, B., Yuan, F., Chen, G., Zhong, T \& MiNG, G. (1984). A new isolate of Bacillus thuringiensis possessing high toxicity against the mosquitoes. Acta Microbiologica Sinica 24, 320-325. 